\title{
Correspondence
}

\section{American Jews, Israel \& Moral Discourse}

\begin{abstract}
Philadelphia, Pa. Dear Sir: Balfour Brickner and David Little are both reasonable men, and therein lies the difficulty of their articles (Brickner's "American Jews, Israel and Public Policy," and Little's "Moral Discourse Under Fire: The Example of the Middle East," both in the January issue of Worldview). Brickner is reasonable, beginning with a sure grasp of the Law and history. Little is reasonable, displaying that rage for universal truths-good for all times and places -so characteristic of university graduates since the Enlightenment.
\end{abstract}

Among those who live in history, Rabbi Brickner would seem to have the better of the argument. American Jews have been in the forefront of the fight for equal justice for black citizens. Israel has risked much in opposing Rhodesian and South African apartheid. Muslim fanatics are responsible for the slaughter of over one-half million villagers in the southern Sudan, many of them Christians (a matter on which the church mission boards are curiously silent!). Scared Jews have backed Procaccino in New York and Yorty in Los Angeles, and-it might now be addedthey elected Rizzo in Philadelphia. But his entire reasonable discourse, logical and accurate as it is, seems to me the statement of a decent man who finds the raw irrationality and lawlessness of politics simply incredible.

This quotation seems to me to epitomize the problem: "Twenty years after the nightmare of McCarthyism, is it possible that there are no politically bold forces in the Christian community or among secular humanists to resist effectively the slander of the dealers in hate and fear? If this is our situation, then far more than the security of
American Jews is in jeopardy. At stake may be the soul of America." The soul of America is at stake, and there is no effective resistance among the Christians or secular humanists. Agnew can help the fascist colonels of Greece shore up their precarious rule, ignoring the pleas of over 160 Greek democrats. Nixon's natural affinity for military jackboots can lead him to try to assist a ruthless dictator in Pakistan, sacrificing-if he could-Bangla Desh and-as he didAmerican honor and prestige in the Indian subcontinent. Senator Eastland can use his powerful chairmanship of the Senate Judiciary Committee to suppress evidence and put a man who is probably a fascist (not a conservative!) on the Supreme Court. In none of these matters, and many others, have the churches or academics shown themselves any better able to resist the slide toward a police state than their German equivalents in 1933-34.

Dr. Little's reasonableness is of another order, essentially speculative. The clue is his deference to Kant's "test of universalizability." I would be grateful for his explanation of how the event of God's gift of the Law on Mount Sinai, or His covenant with Abraham, or what the Christians claim to have happened on Golgotha, can be universalized in that sense! Dr. Little not only rejects Holy History: he rejects historical facts when they don't fit his speculations.

The Arabs were not forced out of the Holy Land. Some of them bet on the wrong side during the attack on Israel in 1948, and the settlement of their claims now awaits the willingness of the Arab League to sit down at the table and make peace. Some of them rejected the appeals of Cairo and Amman radios and stayed, and they now enjoy the benefits of citizenship in a modern nation. As sympathetic as we may feel toward Palestinian refugees, and especially toward their children, we cannot help but contrast the vile politics the Arab governments have made of their lot with the West German resettlement and integration of $14,600,000$ East Germans (most of them former Nazis) in the same period. Dr. Little's entire discussion ignores two basic facts: (a) "the Arabs" include some 400,000 Israeli citizens, to whose rights and conditions he is simply blind; (b) "the Arabs" suffer grievously outside Israel under bellicose and one-party dictatorships whose claim to speak for them is at least suspect.

Dr. Little's real direction comes at the end: "an Israel (though one reduced in size)." Israel accepted severe reduction in size in 1948 in what tumed out to be a fruitless desire for peace with her neighbors. Today she has no intention of sacrificing her security to the idle speculations of world moralists: she doubtless remembers the fate of Latvia, Estonia, Lithuania, Katanga, Biafra, and she certainly remembers the complicity of the "Christian" and Muslim worlds in the destruction of European Jewry.

Dr. Little's Procrustean bed won't fit this case. But that should not disturb him, since in a theoretical exercise one try is as good as another. While the big powers (Russia, the U.S.A., Britain and France) vie with each other to turn back the pages of history and achieve the role of privileged broker of Arab oil (not that the Arab peoples will get the benefits!), the academician can move over to another place and time where the test-case will perhaps work out better.

\section{President, Christians}

Franklin H. Littell

\section{Concerned for Israel}

David Little responds:

In responding to my essay, Professor Littell has put his finger on one critical issue, though not as usefully

[continued on p. 61] 


\section{Correspondence}

[from p. 4]

as he might. The issue concerns the status in moral discussion of "appeals of special privilege," whether these appeals are grounded in a religious belief in special revelation, or in an ideological belief in some form of "manifest destiny." Professor Littell accuses me of "rejecting Holy History" and of illicitly identifying what he apparently regards as a special set of prescriptions revealed by God on Mount Sinai, or revealed in the life and death of Jesus, with some "universal," rational morality. In doing that, I am, he believes, guilty of failing to give appeals of special privilege their due.

But what is their due? If there is a clear answer to that question, Professor Littell does not begin to supply it. I do not have a fixed position on this question-I believe it needs extensive scrutiny. But 1 do have a number of doubts about any position that suggests that policies based on appeals of special privilege ought to be considered morally binding by those not in the "privileged" position. It is not hard to think of historical examples of such appeals which most people, including, I imagine, Professor Littell, would find at least morally questionable; for instance, Cromwell's Irish campaign, or United States policies based on a vision of "the white man's burden," and the like.

Now the question is, are some, though not necessarily all, of the Zionist arguments in favor of a Jewish state in Israel based on similar appeals of special privilege, as I have specified the term? I believe the answer is yes, and the first quotation from former Prime Minister BenGurion (p. 35) would count, I believe, as a rather clear example. I see no reason to regard Ben-Gurion's assertion as any less morally dubious than, say, justifications by American leaders of the late nineteenth century for a policy of American expansionism. (In order that I may not be accused of applying to others standards I refuse to apply to my own tradition, I emphasize that many of these leaders were Protestant Christians who employed specifically Christian appeals to justify "the right" of American expansion.)

However, as I point out in the article, Zionists have not rested their case exclusively on appeals to special privilege. They have argued "from need," and thus have invoked the facts of Jewish persecution. But this argument is an appeal to "universal" moral standards, in the sense that it is an appeal to the "basic justification of all human demands . . .," as Jabotinsky so eloquently puts it (p. 35). During World War II and immediately thereafter, it was this appeal that made moral sense to people and provided widespread justification for the development of Israel. Whether this argument from need suffices to outweigh Arab claims or not requires careful consideration. (For some peculiar reason, the editors excised my discussion of this crucial matter, and I cannot go into it now.) But the main point is that a discussion of these arguments properly goes on in terms of what is justifiable from the point of view of "all human demands," rather than from the point of view of claims of special privilege, such as I mentioned. In short, this aspect of the discussion properly involves something approaching "universal" moral standards. Accordingly, it conforms to my specification of the word "moral."

As a matter of fact, Professor Littell himself presupposes my specifications of "moral" when he goes on to claim that the Arabs "were not forced out of the Holy Land." The factual assumption is that, for one reason or another, many Arabs consented to leave, while the rest happily stayed on. Consequently, according to Littell's implied argument, the Israelis cannot be held morally blameworthy, as they did not in fact disregard the rights of the Arabs. I wish to emphasize that the debate between Professor Littell and me at this point is not over the legitimacy of universal standards of morality; Professor Littell has apparently al- ready assumed something akin to them in his comments. The debate at this point is over the empirical question as to whether the facts about the Arab exodus and the present treatment of the Arabs is as Professor Littell states. On complex empirical matters, such as the recent history of the Middle East, one needs always to be open to new evidence. But surely Professor Littell is aware that, by now, allegations regarding a voluntary Arab exodus are extremely controversial. In the light of rather carefully documented studies like Erskine Childers' "The Other Exodus," we will now need arguments and not assertions.

(continued on p. 62)

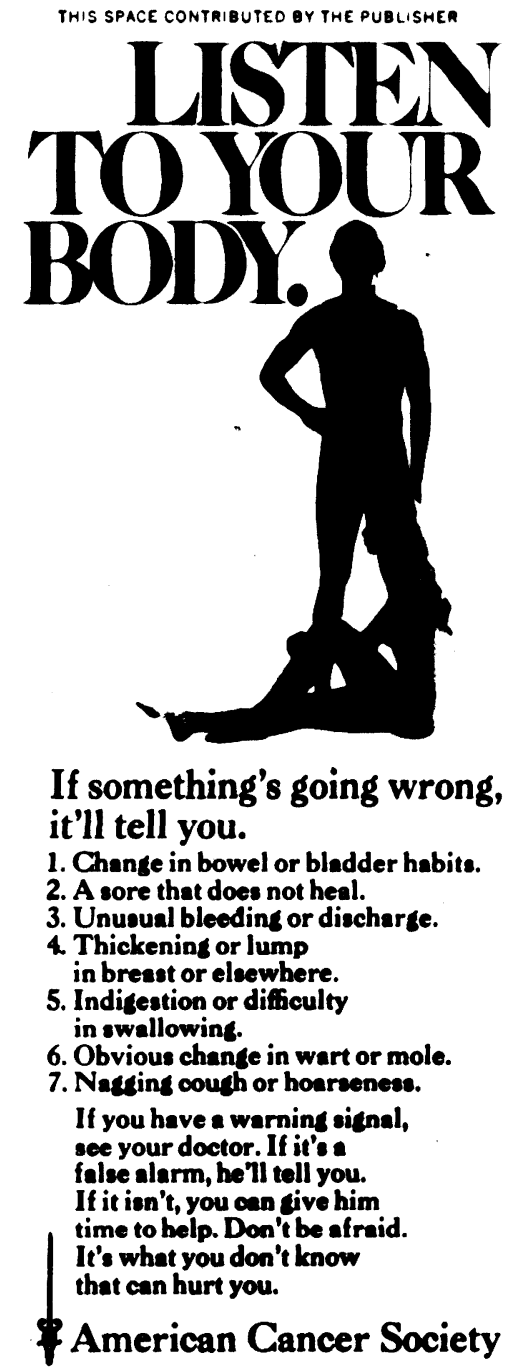

